\title{
Kidney Lymphangioma
}

National Cancer Institute

\section{Source}

National Cancer Institute. Kidney Lymphangioma. NCI Thesaurus. Code C159214.

A rare lymphangioma arising from the kidney. 